\title{
Differences in Public Service Quality on the City Government and the Authority of Batam
}

\author{
A. N. Barkah, Dwi Kartikasari* \\ Politeknik Negeri Batam \\ Batam, Indonesia \\ *dwi@polibatam.ac.id
}

\begin{abstract}
As a free trade zone, Batam is special in the sense of its dualism in the bureaucratic process that sometimes overlapped between two government agencies that is the city government of Batam and the Free Trade Zone Authority of Batam. This dualism may lead to poor public perceptions of quality services. Thus, this study is to prove: 1) whether the public really perceives a poor quality of public services of the city government of Batam and the Free Trade Zone Authority of Batam, and 2) if there is a significant difference on how the public perceives the quality of public services of the city government of Batam and that of the Free Trade Zone Authority of Batam. This research is a comparative study. The research was conducted in the city of Batam and the population in this study is the community scattered in 12 districts in the city of Batam. As many as 120 respondents were chosen using quota sampling. The author found out that: 1) the public perception over the variables of quality of service to the City Government and the Authority of Batam is generally good, neither poor nor great, and 2) there is a significant difference in the perception of the public on the variable quality of service on the Batam City Government and the Authority of Batam where the public perceives that the Authority of Batam delivers better services than the Batam City Government.
\end{abstract}

Keywords-free trade zone; public service quality; city government

\section{INTRODUCTION}

Public services have a key role even vital to the economic and political life. But the quality of public services in Indonesia until now generally been good, not great. As such, the government is constantly working to simplify the bureaucratic process in Indonesia by cutting the bureaucratic process and also improving the quality of service both by the central government and the local government. It is seen as an attempt to foster public confidence in the government that lately has been declining.

As a result of the government efforts to improve the bureaucracy in the economic sector, the World Bank has released Ease of Doing Business (EODB) index in Indonesia rose from rank 91 in 2017 to rank 72 in 2018. That is, EODB in Indonesia rose 19 ratings. Indonesia's rank is above several developing countries such as South Africa (82), India (100), Philippines (113), and Brazil (125). The World Bank based this ranking on several indicators including the achievement of the public sectors (governments) in improving business regulation and investment in their respective countries [1].
As we all know, the government's main function is to serve the community. Thus, the government should continue to improve service quality. This is in line with the National Medium-Term Development Plan (NMTDP) from 2015 to 2019 pursuant to Presidential Decree Number 2 of 2015, which demanded the Central Government and Local Government to comply with Law Number 25 of 2009 on Public Service. Public services are services which produce public goods such as roads, bridges, and markets, as well as public services that process licensing, identity card processing, and other administration needs.

The quality of services provided by the government to the public can be reflected in the many comments and complaints that are often found in mass media such as social media, television and newspapers. Most people concern about procedures and working mechanisms of service that looks like "beating around the bush", not transparent, less informative, less accommodating, inconsistent, as well as insufficient service and infrastructure facilities [2].

The poor quality of public services leads to a crisis of confidence in society towards the public bureaucracy [3]. This crisis of public confidence occurred not only to the central government but also the local government.

Although Indonesia has experienced a significant rise in the rankings, Indonesia is still trying to catch up EODB index with other countries in Southeast Asia by improving investment areas like that in Batam [4]. Batam is a city with 329 islands located between the Straits of Malacca and Singapore thus is located very strategically when compared to other cities in Indonesia. In recent years, Batam is set up as a Free Trade Zone along with Bintan and Karimun referring to Law Number 36 of the Free Trade Zone and Free Port and then changed several times through PERPU, thus enacted into Law Number 44 of 2007 [5].

Batam has approximately 1647.83 square kilometer of sea and 612.5383 square kilometer of land [5]. To guarantee that Batam has everything it needs to grow, the central government establish two government agencies namely the City Government of Batam and the Free Trade Zone Authority of Batam (BP Batam). Batam City Government takes care of all the administrative needs and civil registration for the population. While the Authority of Batam takes care of the governance of land and investments in Batam.

Batam City Government received a yellow predicate from Ombudsman of the Republic of Indonesia, related to 
conformity to the standards of public services. Batam gets an average value of 71.03. This figure is still below the Tanjungpinang (77.07) and the Riau Islands Province (74.83), although both the later ones are in the same the yellow zone considered as medium level of public service quality. No cities or regencies in Riau Islands reach green zone [4].

The dualism between the Batam City Government and the Authority of Batam may result in a burdensome bureaucratic process because some procedures should be pursued through both institutions. This unique procedure may hurt the image of both institutions. Thus, the authors are interested in analyzing 1) whether the public perceives poor quality of public services of the city government of Batam and the Free Trade Zone Authority of Batam, and 2) if there is a significant difference on how the public perceives the quality of public services of the city government of Batam and that of the Free Trade Zone Authority of Batam. This study is expected to benefit the municipal government and the Authority of Batam to improve public trust.

\section{LITERATURE REVIEW}

\section{A. Perception}

Perception is the process used by the individual to select, organize, and interpret input information to create a picture of the world that has meaning [6]. Humans catch the objects of perception around them through their senses [7]. Perception occurs when they receive external stimuli which then enter the brain in which there is a process of thinking that eventually materialized into an understanding. From the definition above, it can be concluded that the perception is individual responses that are captured by means of his senses and could lead to an understanding of the observed object. The process of perception as follows: Object creates a stimulus, and the stimulus is received by the senses and then forwarded by the sensory nerves to the brain. After that there was the process the brain as the center of awareness so that people realize what is seen, what is heard, or what touched [8].

\section{B. Public Service}

Ministry of State Apparatus Empowerment (Menpan) Decree Number 63 of 2003 defines public service as any service undertaken by public service providers in an effort to meet the needs of service recipients according to implementation of the provisions of the legislation. The public service is the fulfillment of desires and needs of the community by state officials [8].

\section{Quality of Service}

The quality of public services provided by the government must pay attention to the satisfaction of the recipient of the service. Simply put, the quality of service can be interpreted as a measure of how good a given service is able to correspond with customer expectations [9]. Quality of service can also be defined as a comparison between the expectations of customers to the company in fulfilling the needs and with the customers' perception of the performance of the services [10]. There are five dimensions of service quality that are important to customer service [11], namely:
- Tangibility, the aspect of the physical facilities or equipment, as well as the appearance of personal service provider that influence the quality of service

- Reliability, a measure of how reliable, accurate and consistent in doing the service in accordance with the customer desires. Reliability reflects the ability to deliver what an organization promises

- Responsiveness, the ability to help customers by providing fast and responsive service.

- Assurance, the ability to provide something that can be believed (safe and guaranteed reliability) by the customer.

- Empathy, the level of care and individual attention given to customers.

\section{Hypothesis}

The hypothesis used in this study is a comparative hypothesis [12] that is formulated as follows. Quality of service can be determined by comparing the perceptions of customers for the services they actually receive [13]. Quality of service can also be seen by comparing the customer expectations with customer perception of performance of the services received.

$\mathrm{H}_{0}$ : There is no significant differences in the public perception on the service quality variables between that of the City Government of Batam and that of the Authority of Batam.

$\mathrm{H}_{1}$ : There is a significant difference in the public perception on the service quality variables between that of the City Government of Batam and that of the Authority of Batam.

\section{METHODS}

\section{A. Types of Research}

This study uses a quantitative approach. This study analyzes public perception on the variables of quality of service with dimensions of tangibility, reliability, responsiveness, assurance and empathy of the Batam City Government and the Authority of Batam. Then, the authors analyze whether there is any significant difference in the public perception of both these institutions. This research uses primary data that are provided by the questionnaire which sent directly to the respondents.

\section{B. Population and Sample}

The target samples are those of the Batam's population to ever receive public services or dealing with service units provided in the area of Batam. The sampling technique used in this study is quota sampling. In this study, the authors identified 120 respondents representing each districts in a balanced gender distribution as follows:

TABLE I. DISTRIBUTION OF RESPONDENTS

\begin{tabular}{|c|c|c|c|}
\hline \multirow[t]{2}{*}{ Districts } & \multicolumn{3}{|c|}{ Number of Respondents } \\
\hline & Man & Woman & Total \\
\hline Belakang Padang & 5 & 5 & 10 \\
\hline Bulang & 5 & 5 & 10 \\
\hline Galang & 5 & 5 & 10 \\
\hline Sungai Beduk & 5 & 5 & 10 \\
\hline Sagulung & 5 & 5 & 10 \\
\hline Nongsa & 5 & 5 & 10 \\
\hline
\end{tabular}


Table 1. Cont.

\begin{tabular}{|l|l|l|l|}
\hline Batam Kota & 5 & 5 & 10 \\
\hline Sekupang & 5 & 5 & 10 \\
\hline Batu Aji & 5 & 5 & 10 \\
\hline Lubuk Baja & 5 & 5 & 10 \\
\hline Batu Ampar & 5 & 5 & 10 \\
\hline Bengkong & 5 & 5 & 10 \\
\hline Total & 60 & 60 & 120 \\
\hline
\end{tabular}

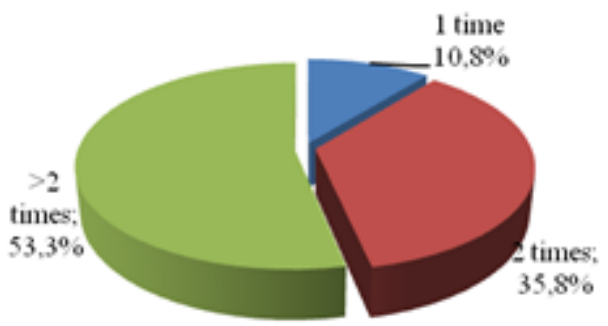

Fig. 1. Respondents intensity in dealing with Batam City Government.

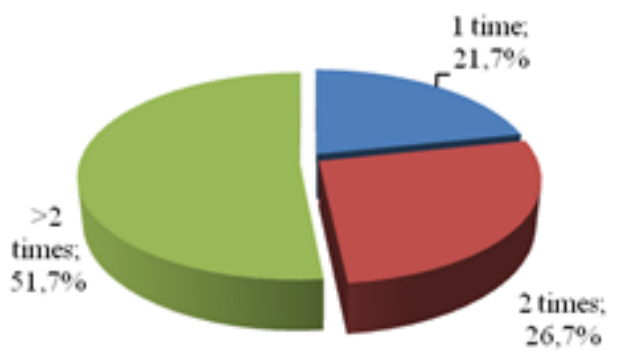

Fig. 2. Respondents intensity in dealing with Batam Authority.

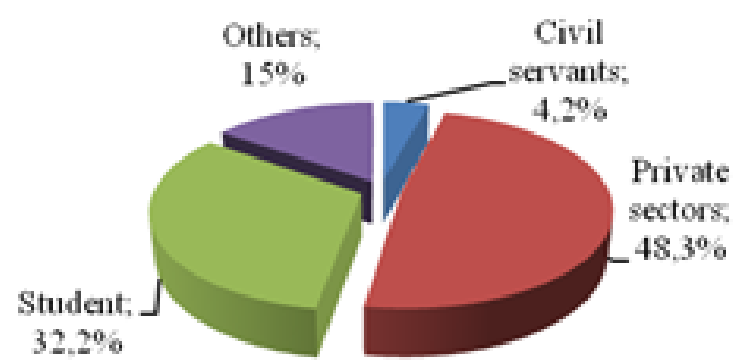

Fig. 3. Respondents Professions.

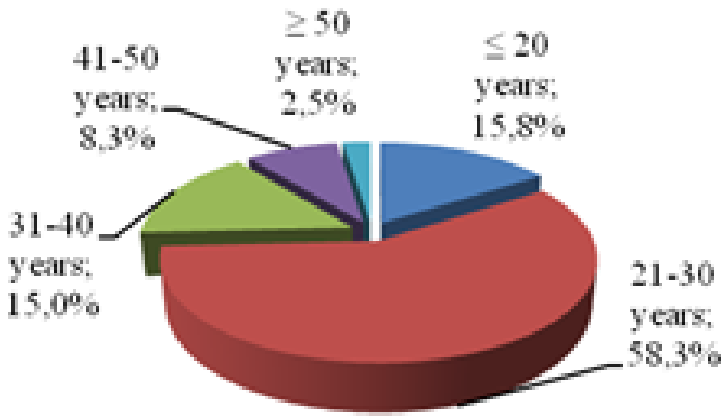

Fig. 4. Respondents Age.

The authors use the 5 Likert scale from 1 representing negative response to 5 representing positive response. The Likert scale is an ordinal scale that is successively processed as interval scale and thus analyzed [14]. It can be seen from figure
1 to 4 above that the respondents are mostly employees of private sectors, age between 21-30 years, and have dealt with both Batam city government and Batam authority more than twice in their lifetime.

\section{Validity Test}

The authors use Corrected Item-Total Correlation by means of correlating each item score with a total score. The results are then compared with the r table with $\alpha=5 \%$ thus $\mathrm{r}$ table $=0.179$. If $\mathrm{r}$ count $>\mathrm{r}$ table then declared invalid. A summary of the validity of the test results can be seen in the following table:

\section{TABLE II. RESUlTS OF VALIDITY TEST}

\begin{tabular}{|c|c|c|}
\hline Item & $\begin{array}{c}\text { r count } \\
\text { City } \\
\text { Govt }\end{array}$ & $\begin{array}{c}\text { r count } \\
\text { FTZ } \\
\text { Authority }\end{array}$ \\
\hline Facilities provided are interesting & 0.347 & 0.276 \\
\hline The lounge area is comfortable & 0.267 & 0.385 \\
\hline The waiting room is clean and tidy & 0.231 & 0.385 \\
\hline Full supportive equipment & 0.279 & 0.337 \\
\hline Attendant are attractive in appearance & 0.637 & 0.418 \\
\hline $\begin{array}{l}\text { Officers provide service according to } \\
\text { appointment }\end{array}$ & 0.373 & 0.191 \\
\hline Officers provide timely service & 0.341 & 0.394 \\
\hline $\begin{array}{l}\text { The clerk inform you when the service } \\
\text { promised is to be realized }\end{array}$ & 0.216 & 0.406 \\
\hline $\begin{array}{l}\text { The clerk is responsible in solving the problem } \\
\text { if it occurs during service }\end{array}$ & 0.311 & 0.303 \\
\hline $\begin{array}{l}\text { Officers provide services } \\
\text { accurately }\end{array}$ & 0.191 & 0.222 \\
\hline $\begin{array}{l}\text { Officers help those who have difficulty or } \\
\text { confusion }\end{array}$ & 0.231 & 0.482 \\
\hline $\begin{array}{l}\text { Officers swiftly deal with complaints or } \\
\text { problems you face }\end{array}$ & 0.307 & 0.615 \\
\hline $\begin{array}{l}\text { Officers are ready and responsive to your } \\
\text { request }\end{array}$ & 0.316 & 0.477 \\
\hline $\begin{array}{l}\text { Officers have extensive knowledge to answer } \\
\text { your questions }\end{array}$ & 0.191 & 0.327 \\
\hline $\begin{array}{l}\text { Officers make you feel comfortable when } \\
\text { receiving services }\end{array}$ & 0.242 & 0.451 \\
\hline $\begin{array}{l}\text { Officers have a good manners when providing } \\
\text { services }\end{array}$ & 0.187 & 0.238 \\
\hline You can easily contact the public service & 0.193 & 0.198 \\
\hline The clerk give attention to you & 0.285 & 0.320 \\
\hline $\begin{array}{l}\text { Officer understand what you want and always } \\
\text { listen your suggestions and complaits }\end{array}$ & 0.258 & 0.246 \\
\hline
\end{tabular}

\section{Reliability Test}

The instruments is called reliable when the value Crohbach. Alpha $(\alpha)>0.600$

TABLE III. RESUlTS OF RELIABILITY TEST

\begin{tabular}{|l|l|c|}
\hline \multirow{2}{*}{ Variable } & \multicolumn{2}{|c|}{ Reliability } \\
\cline { 2 - 3 } & \multicolumn{1}{|c|}{$\begin{array}{c}\text { Cronbach Alpha City } \\
\text { Govt }\end{array}$} & $\begin{array}{c}\text { Cronbach Alpha FTZ } \\
\text { Authority }\end{array}$ \\
\hline Service quality & 0.676 & 0.777 \\
\hline
\end{tabular}

It can be concluded from the above table that the two variables of the study are reliable. 


\section{DATA ANALYSIS}

\section{A. Descriptive Analysis}

The average value of the City Government of Batam in tangible dimension is 3.09 (good), the dimensions of reliability is 2.73 (good), responsivess dimensions is 2.84 (good), assurance dimension is 3.01 (good) and the empathy dimension is 2.78 (good). Batam City Government should give more attention to the dimension of reliability and empathy.

TABLE IV. MEAN OF Quality SERVICES DesCRIPTIVE

\begin{tabular}{|l|l|l|}
\hline \multicolumn{1}{|c|}{ Dimension } & \multicolumn{1}{c|}{ City Government } & FTZ Authority \\
\hline Tangibility & 3.09 & 3.28 \\
\hline Reliability & 2.73 & 2.87 \\
\hline Responsivess & 2.84 & 2.95 \\
\hline Assurance & 3.01 & 3.14 \\
\hline Empathy & 2.78 & 2.90 \\
\hline
\end{tabular}

While the average value of the Authority of Batam in tangible dimension is 3.28 (very good), the reliability dimension is 2.87 (good), responsivess dimensions is 2.95 (good), the assurance dimension 3.14 (good) and empathy dimensions is 2.90 (good). The Authority of Batam should give more attention to the dimension of reliability.

While the average value of the Authority of Batam in tangible dimension is 3.28 (very good), the reliability dimension is 2.87 (good), responsivess dimensions is 2.95 (good), the assurance dimension 3.14 (good) and empathy dimensions is 2.90 (good). The Authority of Batam should give more attention to the dimension of reliability.

The above table shows that generally, respondents perceive that public services delivered by the Authority of Batam is better in all dimensions than those by Batam City Government.

TABLE V. T-TeST RESUlTS

\begin{tabular}{|l|l|l|}
\hline \multicolumn{1}{|c|}{ Items } & \multicolumn{1}{|c|}{ Value } & Conclusion \\
\hline $\mathrm{t}$ & -4.968 & Significantly different \\
\hline sig. (2-tailed) & 0.000 & \\
\hline
\end{tabular}

Because $\mathrm{t}$ value $<\mathrm{t}$ table $(-4.968<-1.980)$ and significance level of $5 \%(0.05)$ obtained sig. (2-tailed) was 0.000. Sig. (2tailed) $<0.05$ then $\mathrm{H}_{0}$ is rejected. It can be concluded that there is a significant difference in the public perceptions on quality variables of the Batam City Government and the Authority of Batam.

\section{CONCLUSIONS AND SUGGESTIONS}

\section{A. Conclusions}

Based on the discussion of the results, it could be concluded as follows:
- The public perception on the variable quality of service to the City Government and the Authority of Batam Batam is generally good.

- There is a significant difference in the public perception on the variable quality of service of the Batam City Government and the Authority of Batam.

- The people of Batam generally perceive that public services delivered by the Authority of Batam are better in all dimensions than those by Batam City Government.

\section{B. Suggestions}

This study suggests as follows:

- Batam City Government and the Authority of Batam is expected to improve the quality of service in each unit of services especially on those items statement that has votes unsatisfactory such as those of reliability dimensions.

- Further research may investigate the effect of dualism of power to the quality of public services.

\section{REFERENCES}

[1] The World Bank Doing Bussiness. http://www.doingbusiness.org/rankings. 2018

[2] Ombudsman Republik Indonesia. Kabar Perwakilan. Retrieved on March 2nd. 2018.

[3] The World Bank. Doing Bussiness http://www.doingbusiness.org/rankings. 2018.

[4] Ombudsman Republik Indonesia. Kabar Perwakilan. Retrieved on March 2nd. http://www.ombudsman.go.id/perwakilan/news/r/pwk-Pengaduan-Ke-Ombudsman. 2018.

[5] U. Silalahi. "Kepercayaan Publik Kepada Pemerintah Daerah Pasca Orde Baru", Jurnal Ilmu Administrasi Negara 11 (2) pp 167-79. 2011

[6] Data Ombudsman Republik Indonesia Cabang Kepulauan Riau 2017. Ringkasan Eksekutif. 2017.

[7] BPS Kota Batam 2016 Penduduk Kota Batam Menurut Kecamatan dan Jenis Kelamin, 2011-2016 Retrieved on November 20th https://batamkota.bps.go.id/linkTableDinamis/view/id/23. 2016.

[8] P. Kotler and K.L. Keller. Manajemen Pemasaran ed 12 (Jakarta: Indeks). 2009.

[9] B.S. Duwit, V.A. Kumurur and I.L. Moniaga. Persepsi Pedagang Kaki LimaTerhadap Area Berjualan Sepanjang Jalan Pasar Pinasungkulan Karombasan Manado. Sabua 7(2) pp 419-27. 2015.

[10] S. Rusnani. Persepsi Masyarakat Tentang Pelayanan Publik di Kantor Kelurahan Handil Bakti Kecamatan Palaran Kota Samarinda. Ejournal Administrasi. 2013

[11] F. Tjiptono. Service Manajemen Mewujudkan Layanan Prima (Yogyakarta: Andi). 2008

[12] I. Sukmawati and J.D.D. Massie. Pengaruh Kualitas Pelayanan Dimediasi Kepuasan Pelanggan dan Kepercayaan Pelanggan Terhadap Loyalitas Pelanggan Pada PT Air Manado. Jurnal EMBA 3 (3) pp 72942. 2015

[13] H. Windasuri and H. Susanti. Excellent Service : The Secret Of Building A Service Organization (Jakarta: Gramedia Pustaka Utama). 2017.

[14] Sugiyono. Statistika Untuk Penelitian (Bandung: Alfabeta). 2017. 